\title{
Vähän koulutetut aikuiset ja Noste
}

\section{- kokemuksia koulutusinnovaatiosta}

\author{
JONNA TOSSAVAINEN \& KIRSTI HULKARI
}

\begin{abstract}
Vuonna 2003 käynnistynyttä Noste-koulutusohjelmaa voidaan pitää valtiollisena interventiona, positiivisen diskriminaation muotona tai sosiaalisena innovaationa vähän koulutettujen aikuisten koulutustason nostamiseksi. Innovaatioksi Noste-ohjelma voidaan tulkita siihen sisältyvien uusien toimintamallien ja käytäntöjen vuoksi. Artikkelissa kuvatussa tutkimuksessa tarkastellaan Nosteen kaltaisen koulutusinnovaation leviämisen ehtoja matalasti koulutettujen keskuudessa kouluttajien, työnantajien ja opiskelijoiden itsensä kokemana.
\end{abstract}

Noste-ohjelma oli monivuotinen Suomen opetusministeriön, työministeriön ja työelämäjärjestöjen yhteistyössä toteuttama valtakunnallinen hanke, jonka tarkoituksena on kohottaa vailla toisen asteen tutkintoa olevien 30-59-vuotiaiden aikuisten koulutustasoa ja ATK-osaamista. Noste-ohjelman koulutuspoliittisena tavoitteena on edistää koulutuksellista tasa-arvoa parantamalla vähän koulutettujen aikuisten mahdollisuuksia tutkinnon suorittamiseen. Aiemman aikuiskoulutustutkimuksen pohjalta Nosteen kohderyhmää voidaan pitää haasteellisena. Vaikka aikuiskoulutukseen osallistuvien määrä on kasvanut, näyttää perinteinen koulutuksesta tiedottaminen tuottavan vuodesta toiseen saman lopputuloksen: koulutusmahdollisuuksia hyödyntävät erityisesti korkean koulutustaustan omaavat. Vailla toisen asteen tutkintoa olevat työntekijät, varsinkin miehet, osallistuvat koulutukseen edelleen selvästi vähiten. (ks. Tilastokeskus: Blomqvist, Ruuskanen, Niemi \& Nyyssönen 2002; Pohjanpää, Niemi \& Ruuskanen 2008.) Vähän koulutetuille aikuisille koulutukseen osallistuminen on usein "välttämättömyyden valinta". Koulutukseen osallistutaan vasta sitten, kun muita vaihtoehtoja ei enää ole. Tämän vuoksi vähän koulutettujen aikuisten osallistumisen edistäminen on ollut koulutuspoliittisena tavoitteena ja erityisohjelmien kohteena useiden Euroopan maiden koulutuspolitiikassa. (Antikainen 2005; 2009.)

Noste-ohjelmaa voidaan eri yhteyksissä tarkas- tella valtiollisena interventiona, positiivisen diskriminaation muotona tai sosiaalisena innovaationa vähän koulutettujen aikuisten koulutustason nostamiseksi (Antikainen 2008; Hulkari 2008). Innovaatioksi Noste-ohjelma voidaan tulkita siihen sisältyvien uusien toimintamallien ja käytäntöjen vuoksi. Näitä ovat muun muassa erityisrahoitettu hakeva toiminta, verkostoituminen sekä aikuisille kohdennetut ohjaus- ja tukitoimet. Koulutuksen järjestäjät ovat etsineet ja kannustaneet kohderyhmää koulutuksiin, tarjonneet kohderyhmään kuuluville henkilöille epätavanomaisia yksilöllisiä koulutusmuotoja sekä pyrkineet järjestämään opiskelun tukitoimenpiteitä uudessa laajuudessa. Ohjelmassa kehitettyjä hyviä käytäntöjä on pyritty levittämään ja juurruttamaan aikuiskoulutukseen.

Tässä kuvatussa tutkimuksessa Noste-ohjelmaa tarkastellaan alun perin markkinointitutkimukseen perustuvan Rogersin (1995) innovaatioiden diffuusioteorian pohjalta, jota 1960-luvulta lähtien on sovellettu laajasti eri tieteenalojen ongelmien tutkimiseen (Seels 1997, 19). Kasvatustieteissä lähestymistapaa on sovellettu muun muassa koulutusreformien ja -ohjelmien sekä verkko-opetus innovaation leviämisen tutkimiseen (Kaivola 2000; Kankaanrinta 2009; Kolehmainen 1997). Artikkelissa pohditaan diffuusioteorian näkökulmasta vähän koulutettujen aikuisten osallistumiseen ja osaamisen kehittämiseen liittyvää problematiikkaa sekä koulutuspolitiikkaan liittyviä haasteita. 


\section{Koulutusinnovaation omaksuminen ja diffuusio yksilötasolla}

Rogers $(2003,11)$ määrittelee innovaation ideaksi, käytännöksi tai tuotteeksi, jota yksilöt pitävät uutena tai jota hyödynnetään uudella tavalla. Innovaatiota voidaan kutsua myös muutokseksi (Fullan 2007, 65-69). Innovaation omaksumisella tarkoitetaan päätöstä innovaation käyttöönotosta tai hyväksymispäätöksen siirtämistä. Diffuusio on prosessi, jonka avulla innovaatio levitetään eri viestintäkanavien avulla sosiaaliseen järjestelmään (Rogers 2003, 18-19).

Ilmiötasolla aikuiskoulutustutkimuksella ja diffuusioteorialla on yhtäläisyyksiä. Vähän koulutettujen aikuisten koulutukseen osallistuminen ja koulutuspäätöksen tekeminen voidaan rinnastaa innovaation omaksumiseen, ja osallistumista edistävän koulutusmyönteisen ajattelutavan leviäminen innovaation diffuusioon. Nosteen kontekstissa diffuusiota voidaan pitää sosiaalisena tapahtumasarjana, joka vähitellen saa aikaan muutoksen kohderyhmän aiemmassa koulutuskäyttäytymisessä. Koulutuspäätöksen tekemiseen vaikuttavat henkilökohtaiset tekijät, kuten elämäntilanne tai taloudellinen tilanne (Kuncaits 2005).

Koulutustiedon saatavuus sekä potentiaalisten käyttäjien kyky hankkia ja hyödyntää tietoa ovat innovaation leviämisen edellytyksiä. Yksilöiden välinen kommunikointi ja henkilökohtaiset kontaktit ovat diffuusion sosiaalisen luonteen mukaisesti muodostuneet Nosteessa mediaa tärkeämmiksi tiedotuskanaviksi (ks. myös Jensen 1999). Kasvokkainen vuorovaikutus on erityisen tärkeää silloin, kun innovaation kokeilemiseen tai omaksumiseen koetaan liittyvän huomattava sosiaalinen, psykologinen tai ekonominen riski. Tämän vuoksi työyhteisössä välittyvät kohderyhmän sisäiset koulutuskokemukset koetaan usein virallista koulutusmarkkinointia vakuuttavammaksi.

Innovaatioiden diffuusiossa tärkeissä rooleissa ovat sosiaalisen systeemin sisään kuuluvat mielipidejohtajat ja ulkopuolelta tulevat muutosagentit, joiden tehtävänä on edistää yhteisön sisäistä muutosta (Rogers 2003, 19, 305-325). Muutosagentit pyrkivät vaikuttamaan yhteisöön ensisijaisesti mielipidejohtajien kautta, jotka puolestaan vaikuttavat organisaation jäsenien mielipiteisiin ja käyttäytymiseen sekä muodollisen asemansa että epävirallisten keskustelujen avulla. Nosteohjelmassa hakevaa toimintaa tekevät henkilöt toimivat työelämässä usein muutosagentin roo- lissa kannustaessaan kohderyhmää koulutukseen ja pyrkiessään vähentämään päätöksentekoon liittyviä riskejä ja epävarmuutta. Mielipidejohtajuus ei edellytä virallista asemaa yhteisössä vaan se määrittyy sosiaalisessa vuorovaikutuksessa ollen yhteydessä henkilön pätevyyteen, sosiaaliseen lähestyttävyyteen sekä yhdenmukaisuuteen järjestelmän normien kanssa. Muutosagenttien rooli korostuu niiden innovaatioiden kohdalla, joiden hyödyt eivät ole helposti tunnistettavissa tai joiden realisointi vie aikaa. (Rogers 1995; Berranger ym. 2001; Caldwell 2003; Sevcik 2004.)

Innovaation omaksumiseen vaikuttaa se, millaisena innovaation suhteellinen hyöty koetaan aiempiin käytössä oleviin välineisiin verrattuna, miten innovaatio sopii yhteen käyttäjän aiempien kokemusten, arvojen ja tarpeiden kanssa sekä miten kokeiltavana ja näkyvänä innovaatio koetaan (Rogers 1995, 20; Rogers 2003, 221222). Vähän koulutetut aikuiset eivät välttämättä koe koulutusta itselleen tärkeäksi tai he kokevat koulutukseen liittyvät riskit siitä saatavia hyötyjä suuremmaksi.

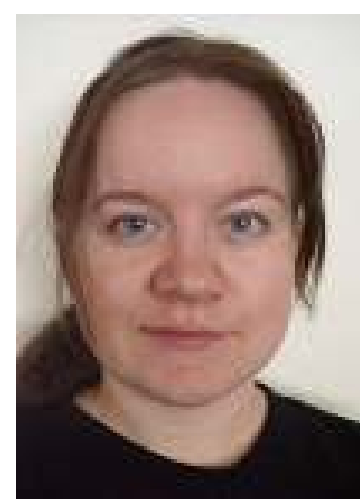

Jonna Tossavainen

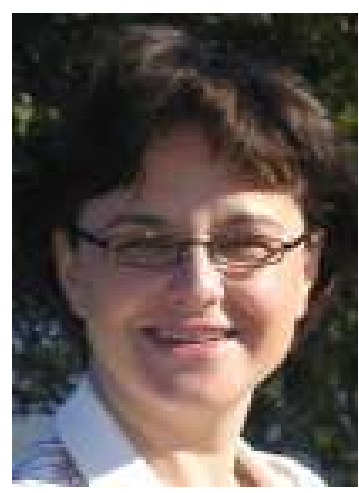

Kirsti Hulkari Koulutuksesta saatavia hyötyjä arvioidaan usein taloudellisesta näkökulmasta pohtimalla tutkinnon rahallista tai ajallista tuottoa, koulutuspalveluiden joustavuutta ja saatavuutta sekä koulutuksen vaikutusta työntekijän omaan asemaan työyhteisössä (vrt. Plouffe ym. 2001). Koulutuksesta saatavat hyödyt tunnistetaan vasta pitkän ajan kuluttua, mikä osaltaan vaikeuttaa pitkäaikaiseen koulutukseen sitoutumista.

Koulutuksen suhteellinen hyöty saatetaan kokea sitä suuremmaksi, mitä enemmän koulutukseen osallistuvia henkilöitä työpaikalla on. Tällöin käyttäjämäärän kasvaminen saattaa alentaa innovaation omaksumiseen liittyvää kynnystä (ks. Rogers 1995). Sellaisten innovaatioiden omaksuminen tapahtuu nopeimmin, joiden tuottama hyöty yksilölle on selkeästi arvioitavissa etukäteen ja joiden 
sosiaalinen imago on vahva. Ratkaisevaa on innovaation koettu hyöty objektiivisen hyödyn sijasta.

Jensen (1999) toteaa, että koulutuksen valintaan vaikuttaa nykyisin enenevässä määrin elämyshakuisuus. Aikuisopiskelijat ovat kuluttajia, joiden päätöksentekoon myös imagotekijät vaikuttavat (ks. Manninen 2004). Varhaiset negatiiviset koulumuistot ja itseluottamuksen puute saattavat muodostua matalasti koulutettujen aikuisten osallistumisen esteeksi (esim. Illeris 2006). Manninen (2004; ks. myös Manninen yms. 2003) on osoittanut koulutustaustan ja koulutusmielikuvien laadun olevan yhteydessä toisiinsa siten, että negatiiviset mielikuvat koulutuksesta painottuvat matalammin koulutettujen ja passiivisten aikuisopiskelijoiden ryhmässä, mikä selittänee myös osallistumattomuuden kasautumista.

Rogers (1995, 22, 37) jakaa innovaatioiden omaksujat viiteen ryhmään siten, että innovaattoreita ovat ensimmäiset 2,5 prosenttia väestöstä. Seuraavat luokat muodostavat aikaiset omaksujat $(13,5$ prosenttia), joihin kuuluvat useimmiten mielipidejohtajat, aikainen enemmistö (34 prosenttia), myöhäinen enemmistö (34 prosenttia) sekä hitaat omaksujat (16 prosenttia). Jokaiseen omaksujaluokkaan kuuluvilla yksilöillä on samankaltaisia piirteitä. Kaksi viimeistä ryhmää kuvaavat hyvin sitä osaa Nosteen heterogeenisestä kohderyhmästä, joka on vaikeimmin tavoitettavissa koulutukseen. Heitä yhdistää traditionaalinen toiminta, muutosten vastustaminen, alhainen koulutustaso ja heikot oppimisvalmiudet, epävarmuus ja varovaisuus sekä vähäiset tietotekniikkataidot. Nämä henkilöt saavat tietoa vertaisiltaan yksilöiden välisessä tiedonvaihdossa sosiaalisen järjestelmänsä sisällä. Näissä ryhmissä uusi innovaatio omaksutaan yleensä vasta sitten, kun siihen liittyvä epävarmuus on saatu poistettua. Innovaation omaksuminen on usein seurausta kasvaneesta ympäristön paineesta.

Ikääntyvien työntekijöiden koulutukseen osallistumiseen vaikuttaa usein työnantajalta tullut aloite, kannustus ja rohkaisu, meneillään olevat organisaatiomuutokset tai muiden ympärillä toimivien ihmisten innostuminen koulutuksesta (ks. Tikkanen \& Nyham 2008, 6; Abrahamson \& Rosenkopf 1997, 289). Mitä matalampi työntekijän asema on, sitä riippuvaisempi hän on työnantajansa tuesta koulutukseen osallistumisessa (Antikainen 2005; ks. myös Ahire \& Ravishandran 2001; Huusko \& Luukkainen 2007).

\section{Data ja analyysi}

Tässä artikkelissa tarkastellaan Rogersin (1995) innovaatioiden diffuusioteorian pohjalta vähän koulutettujen aikuisten koulutukseen osallistumista ja osall istumista edistävän ajattelutavan omaksumista ja leviämistä Nosteen kohderyhmässä. Laadullinen tutkimusaineisto on kerätty teemahaastattelujen avulla hakevan toiminnan tutkimuksen yhteydessä vuosien 2005-2008 aikana. Haastattelut on toteutettu yhteistyössä Joensuun yliopiston tutkijoiden Anne Luukkaisen, Arja Huuskon, Hanne Laukkasen ja Toni Kososen kanssa. Teemahaastatteluihin osallistui 14 työnantajaa, 15 projektipäällikköä ja 17 kouluttajaa (ks. Huusko \& Luukkainen 2007). Tämän lisäksi tutkimusaineistona on hyödynnetty 15 pätevyysluotsin puhelinhaastattelua (Laukkanen 2008). Projektipäälliköt -nimeke käsittää koordinaattorit, seutukoordinaattorit ja hankepäälliköt, vastaavasti kouluttaja -nimeke sisältää kaikki kouluttajan tehtävissä toimivat haastateltavat ja oppisopimustoimiston edustajat. Haastatellut työnantajat olivat työpaikkojen ja yritysten esimiehiä tai heidän määräämiään edustajia (ks. Huusko \& Luukkainen 2007). Haastatteluun osallistuneet projektipäälliköt ja kouluttajat on valittu vaikuttavista ja paljon kohderyhmää saavuttaneista Noste-hankkeista. Haastatellut työnantajat oli valittu näiden vaikuttavien hankkeiden työelämäverkostoista.

Opiskelijoiden $(n=17)$ haastattelut on toteutettu vuosina 2003-2005 (ks. Kokkila 2006). Näissä teemahaastatteluissa kartoitettiin aiempien koulutuskokemusten ja aikuisiän koulutukseen osallistumisen välistä yhteyttä. Tehdyt haastattelut välittävät Noste-kohderyhmän sosiaalista todellisuutta. Koulutusinnovaation omaksumista käsitellään Noste-koulutuksiin hakeutumista ja koulutuspäätöksen tekoprosessia kuvaavissa haastatteluteemoissa. Näissä osioissa kartoitetaan myös koulutuspäätöksen tekemiseen vaikuttavia tekijöitä ja motivaatiota (ks. Laukkanen 2006).

Koulutusinnovaatioiden diffuusiota käsittelevät haastatteluteemat koskevat toimijaverkostoa ja tiedottamisen muotoja sekä hakevan toiminnan toteuttamismuotoja (toimivat ja toimimattomat). Innovaation diffuusioon vaikuttavista taustatekijöistä antavat viitteitä vastaukset, jotka koskevat koulutuksesta saatuja kokemuksia, kouluttajien ja koulutuksen tarvevastaavuutta sekä työyhteisössä käytettyjä kannustuskeinoja. Tutkimuksen analyysirunko on kuvattu kuviossa 1. 
KUVIO 1. Noste-ohjelma asetettuna innovaatioiden diffuusioteorian kehykseen (Rogers 1995 \& 2003;

\section{Noste sosiaalisena innovaationa}

- Uudet toimintamallit (hakeva toiminta, aikuisten ohjaus- ja tukitoimet)

- asennemuutos elinikäiseen oppimiseen kannustamisessa

\section{Diffuusiota edistää}

- oppilaitosverkostot

- hakevaan toimintaan osoitetut resurssit

- viestintäprosessi sosiaalisen verkoston sisällä, johon osallistuvat viralliset ja epäviralliset tahot

\section{Innovaation omaksumiseen liittyvä analyysirunko \\ - koulutuksen suhteellinen hyöty \\ - monimutkaisuus (koulutuksen saatavuus, koulutusjärjestelyt) \\ - kokeiltavuus}

Tutkimusaineisto analysoitiin teorialähtöisen sisällönanalyysin periaatteiden mukaan (ks. Tuomi \& Sarajärvi 2006, 98, 101). Analyysin ensimmäisessä vaiheessa diffuusioteorian pohjalta luotiin analyysirunko. Toisessa vaiheessa aineisto luokiteltiin analyysirungon mukaisesti. Luokittelussa tutkimusaineisto kategorisoitiin koulutusinnovaation omaksumista ja diffuusiota kuvaavien alakäsitteiden alle. Analyysin tarkoituksena oli testata diffuusioteorian käsitejärjestelmää aikuiskoulutuksen kontekstissa. Saatuja tuloksia tulkitaan sekä aikuiskoulutukseen että diffuusioteoriaan liittyvien aiempien tutkimusten valossa.

\section{Vähän koulutettujen aikuisten suhtautuminen koulutukseen}

Työelämässä työntekijöihin kohdistuvat vaatimukset ja odotukset ovat kasvaneet viime vuosina. Kohonneeseen vaatimustasoon ja itsensä kehittämisen paineisiin työntekijät voivat suhtautua joko vältellen tai panostamalla opiskeluun ja ammatissa kehittymiseen (Ruohotie 2000). Koulutus on luonnollinen itsensä kehittämisen ja muutoksen hallinnan väline niille, joilla on oppimiseen sisäinen motivaatio, tarvittavat opiskelutaidot ja halu kehittyä. Tälle aktiiviselle ryhmälle tieto järjestettävästä koulutuksesta riittää kannustimeksi koulutukseen osallistumiselle.

Perinteinen koulutusmarkkinointi ei kuitenkaan tavoita koulutukseen vähän koulutettuja aikuisia. Vetäytyvän ryhmän henkilöt tarvitsevat työelämän vaatimusten perässä pysymiseen ja koulutukseen hakeutumiseen tukea ja kannustusta; juuri hakevalla toiminnalla etsitään näitä henkilöitä, jotka tarvitsevat koulutusta, mutta eivät siihen itse aktiivisesti osallistu. Oppilaitostoimijoiden jalkautuminen työelämään ja kasvokkainen vuorovaikutus on tässä ryhmässä todettu vaikuttavimmaksi hakevan toiminnan muodoksi. (esim. Luukkainen 2006; Kosonen 2008; Huusko \& Luukkainen 2007; Tossavainen 2008b).

Syitä siihen, miksi koulutus ei kiinnosta, saattaa olla monia. Opiskelumotivaation puute vaikeuttaa vähän koulutettujen aikuisten omaehtoista koulutukseen hakeutumista. Koulutukseen motivointi on koettu aikuiskoulutuksessa ongelmallisena nimenomaan vanhemmassa ikäluokassa. Iän myötä oppimismotivaatio heikkenee, kun työn ja oppimisen merkitys vähenee ihmisen elämänkulussa (Paloniemi 2004). Myös toimintaympäristöstä ja työyhteisöstä aiheutuvat paineet vaikuttavat osallistumispäätökseen. Koulutuksesta voi muodostua työntekijään kohdistuva vaade, koska heille koulutus näyttäytyy usein välttämättömyytenä työelämässä pärjäämiseksi (Antikainen 2005; Järvensivu 2006).

Olen ollut korjausrakennuspuolella töissä tähän asti ja siellä on ainakin se vedeneristyshomma sellainen välttämättömyys, jollei sitä passia ole, se on vähän vaikea mennä mitään tekemään, koska rakennuttaja vaatii sen. (opiskelija)

Vähän koulutettujen aikuisten työhön liittyvään 
koulutukseen osallistumisen esteenä ovat usein kiireet työpaikalla ja arjessa, sekä terveyteen ja ikään liittyvät syyt.

\section{Koulutuksen koettu hyöty}

Koulutusinnovaation omaksumiseen vaikuttaa koettu suhteellinen hyöty sekä koulutuksen yhteensopivuus henkilön aiempien kokemusten ja arvojen kanssa (Rogers 1995). Pohdittaessa matalasti koulutettujen aikuisten koulutukseen osallistumista tai koulutuksen merkitystä työelämässä on tiedostettava, että koulutus tai tutkinto ei välttämättä tarkoita yksiselitteistä hyötyä työntekijän näkökulmasta. Koulutus koetaan usein hyödyttömäksi, jos työntekijän toimenkuva ei muutu koulutuksen vaikutuksesta tai urakehitysmahdollisuutta ei ole (Ruohotie 2000). Mikäli koulutuksesta ei koeta saatavan hyötyä, kiinnostus koulutukseen on vähäistä. Koulutuksen potentiaalista hyötyä ei aina pystytä arvioimaan etukäteen, minkä vuoksi päätöksentekoon liittyvä epävarmuus on ymmärrettävää. Koulutukseen motivoi muodollisen pätevyyden saaminen ja sitä kautta työmarkkina-aseman paraneminen. Koulutus koetaan hyödylliseksi, kun se auttaa työn suorittamisessa, työpaikan säilyttämisessä tai mahdollisessa rekrytointitilanteessa. Odotuksiin koulutuksen sisällöistä ja hyödyllisyydestä vaikuttavat aiemmat kokemukset.

Niinku yleensä opiskelussa minnuu on vaivannu se, että ei tunnu oppivan mittään noissa opiskeluissa. Jonninjoutavaa paskanjauhantoo tuntuu 80 prosenttii koulunkäynnistä, että töissä oppii kahessa viikossa sen mitä kolomessa vuodessa koulun penkillä. (opiskelija)

Olen huomannut, että koulutuksesta on ollut jo hyötyä. Vaikka minulla on pitkä työkokemus takanani, huomaan opiskelusta saamastani tiedosta olleen jo hyötyä päivittäisissä askareissani. (opiskelija)

Minulla loppui työt ja ajattelin että olisi edes jotakin, jos tulee työpaikan vaihdos niin olisi hyvä osata tätäkin. (opiskelija)

Useimmat matalasti koulutetut henkilöt arvostavat tutkintoja, mutta kynnys opiskelijaksi ryhtymiseen on monella korkea. Arvokkaiksi mielletyt ominaisuudet ja työmaailmassa käytössä ole- vat toimintatavat ovat usein keskenään ristiriitaisia; toisaalta vaaditaan kouluttautumista, toisaalta siihen ei myönnetä resursseja eikä sitä pidetä kaikissa työnkuvissa tarpeellisena. Kaikilla ei myöskään ole mahdollisuutta työuralla etenemiseen koulutuksen myötä. (ks. Järvensivu 2006.)

\section{Kokeiltavuus}

Rogersin (2003) teoriassa yksi innovaation leviämiseen vaikuttava seikka oli kokeiltavuus. Koulutuksen kontekstissa tämän voi tulkita siten, että yksittäisen henkilön on helpompi sitoutua aluksi lyhytkestoiseen koulutukseen ja päättää vasta saatujen kokemusten pohjalta jatkosta. Vähän koulutettujen aikuisten näkökulmasta osatutkinnot tarjoavat koko tutkintoja paremmat mahdollisuudet kokeilla, miten opiskelu aikuisiällä sujuu. Kokeilunhalu oli yksi tekijä, mikä motivoi opiskelijoita koulutukseen.

Koko tutkinnon suorittaminen pelottaa, että jos olisi näitä tutkinnon osa-alueita, joita voisi suorittaa, niin se olisi ehkä helpompi. Tai aloittaa jollakin ja ehkä sitten jatkaa. (työnantaja)

Halusin kokeilla tuleeko tästä opiskelusta tässä iässä mitään. (opiskelija)

Haastatteluaineiston perusteella osatutkintomahdollisuudesta ei ollut käyty paljoakaan keskustelua koulutustarpeisiin liittyvissä neuvottelutilanteissa. Osatutkintojen avulla pystytään vastaamaan usein paremmin yksilöiden ja yritysten koulutustarpeisiin.

Noste-ohjelmassa on vähän koulutettujen aikuisten osallistumista pyritty edistämään järjestämällä koulutus mahdollisimman lähellä palvelun käyttäjiä ja kiinnittämällä huomiota koulutusjärjestelyjen joustavuuteen. Kulkuyhteydet ovat varsinkin haja-asutusalueella koulutukseen osallistumisen ongelmana, jolloin koulutuspalveluiden saavutettavuus saatetaan kokea monimutkaisena.

Työpaikoille tai edes samalle paikkakunnalle tuotu koulutus koettiin ratkaisuksi pitkiin välimatkoihin, jotka vaikeuttivat koulutukseen osallistumista.

Niin on, ja tällaiset pienempien paikkakuntien ihmiset aina kritisoivat tätä (kaupunki) keskeisyyttä opetustarjonnassa. [...] Toivoisin, että ymmärrettäisiin tälleen, että pienemmät 
paikkakunnatkin, jotka haluavat lisätä osaamisentasoa, että ei tämä koulutus olisi vaan näillä isoilla paikkakunnilla. (kouluttaja)

\section{Päätöksenteon luonne}

Keskeinen innovaation omaksumisnopeuteen vaikuttava tekijä on innovaatiopäätöksen luonne. Innovaation omaksuminen voi tapahtua vapaaehtoisena päätöksenä, yhteisön päätöksenä tai auktoriteetin määräämänä (Rogers 1995, 28-29). Vailla toisen asteen tutkintoa olevat aikuiset osallistuvat koulutukseen usein työnantajan aloitteesta ja heidän oma-aloitteinen koulutukseen osallistumisensa on harvinaisempaa kuin korkeammin koulutetuilla (Tossavainen 2008a). Auktoriteettipäätös edistää koulutusinnovaation omaksumista, mutta aiheuttaa myös eniten vastarintaa ja saattaa rajoittaa innovaation syvällistä omaksumista käytäntöihin.

Tuo meijän työnjohtaja, mikä meillä on, niin hän esitti sitä [koulutusta] viime talavena ja minä olin kyllä ihan kerta kaikkiaan vasten sitä, että minä en tällä ikkee kerta kaikkiaan lähe mihinkään, että se on tyhjä tällä ikkee lähtee kouluttammaan mittään ja kyllä se vain syksyllä sai minut innostummaan sitten. (opiskelija)

Meidän on annettu ymmärtää että tämä on vähän sellainen vapaaehtoinen pakko. Koulutusta tyrkytettiin tasa-arvon nimissä, jotta osaisimme edes lukea sähköpostin. (opiskelija)

Varsinkin ikääntyvillä ja vähän koulutetuilla aikuisilla saattaa olla vaikeuksia tunnistaa omia koulutustarpeitaan. Koulutukseen osallistuminen edellyttää heidän kohdallaan työnantajalta tullutta aloitetta (ks. Tikkanen \& Nyham 2008). Vaikka auktoriteettipäätöksen avulla koulutukseen osallistujien määrää pystytään kasvattamaan, on vapaaehtoisuuteen perustuva päätös yksilön oppimisen kannalta tuloksellisin (myös Rogers 2003). Opiskelijamäärältään laajimmat koulutukset ovat Noste-ohjelmassa syntyneet kolmikantayhteistyön tuloksena (Laukkanen 2008).

\section{Muutosagentit}

Hakevaa toimintaa organisaatiossa tekevä henkilö voidaan ymmärtää muutosagenttina, jonka tehtävänä on kannustaa, motivoida ja rohkaista koh- deryhmää koulutukseen sekä herättää kiinnostusta koulutusta kohtaan. Kannastaan epävarmoille ja vähemmän aktiivisille henkilöille pienryhmissä käydyt keskustelut ja henkilökohtaiset suhteet ovat päätöksenteon kannalta usein mediaa ja julkista "kampanjatiedottamista" tärkeämpiä (myös Weiman 1994). Hakevan toiminnan tavoitteena on ollut madaltaa koulutukseen osallistumisen kynnystä henkilökohtaisten keskustelujen avulla. Vähän koulutettujen aikuisten kohdalla tämä on tarkoittanut yhteistä koulutuksen hyötyjen ja riskien punnitsemista.

Kyllä monelle Noste-opiskelijalle on tosi suuri kynnys lähteä tähän hommaan. Pitää saada ne kaikki palikat kuntoon, jotta se mahdollisuus on lähteä koulutukseen. Ja se on se missä meidän apua tarvitaan siihen uskon luomiseen, että vaikka sinä järjestelet sen elämäsi uusiksi niin tämän avulla saat sen mitä olet tavoittelemassa. (kouluttaja)

Useimmilla on se oma uteliaisuus ja nälkä olemassa jo, mutta että ihan keskustellaan, jutellaan, ja punnitaan niitä etuja ja haittoja. (kouluttaja)

Koulutusinnovaatiota ei yrityksissä omaksuta pelkän tiedotuksen perusteella, vaan muutosagentin toiminnan rooli ja merkitys, samoin kuin innovaation omaksumisen syyt vaihtelevat eri omaksujaryhmien välillä diffuusion edetessä (myös Waarts ym. 2002).

\section{Mielipidejohtajilta ja työtovereilta saadut kokemukset prosessissa}

Vähän koulutettuja aikuisia kannustaa koulutukseen erityisesti tuttavien, työkavereiden ja pätevyysluotsien myönteiset kokemukset sekä työnantajan tuki koulutukselle (Antikainen 2005). Myöhäiset innovaatioiden omaksujat hyötyvät aiemmilta omaksujilta saaduista kokemuksista (Rogers 1995, 22, 37). Muilta kuullut myönteiset kokemukset ja tieto vähentävät innovaatioon kohdistuvaa riskiä ja epävarmuutta ja edistävät siten koulutusinnovaation leviämistä työyhteisössä. Innovaation leviäminen on itsestään jatkuvaa, kun riittävä määrä (kriittinen massa) innovaation omaksujia on saavutettu. Osallistujamäärän kasvaminen organisaatiossa alentaa innovaation omaksumiseen liittyvää kynnystä myös koulutuskontekstissa. (Rogers 2003; Nelson ym. 2004.) 
Sille ensimmäiselle kurssille oli vähän varovasti se ilmottautuminen, mutta seuraavalle sitten jo oli kyselty näiltä, että minkälaista siellä on, ja sitten rupesikin näitä vanhaa poruk$k a a$, että seuraavassa varmaan on sit näitä nostelaisia huomattavasti enemmän, että sinne rupes sitten aktivoitumaan sitä. (työnantaja)

Perustelen sillä, että kun me ollaan nää 450 reilut tutkintoa tehty ja kun on rohkaisevia esimerkkejä, niin ei oo ollu vaikeuksia saada uusia. Melkein niin päin että millon on mun vuoro. (työnantaja)

Mielipidejohtajat voivat vaikuttaa myös kielteisesti koulutusinnovaation leviämiseen. Luottamusmiehet näyttävät toimivan mielipidejohtajan roolissa erityisesti sellaisissa työyhteisöissä ja toimialoilla, joissa ammattiyhdistysliikkeen asema on vahva. Työnantajan negatiivinen suhtautuminen voi vastaavasti olla koulutusinnovaation leviämisen esteenä.

Jos luottamusmies haraa vastaan, ei takuulla tuu mitään, koska se saa väen negatiiviseksi ja pystyy varmasti torpedoimaan. Ja taas jos työnantaja ei oo innokas, niin eihän sitä luottamusmies ja työntekijät pysty viemään (pätevyysluotsi)

Omassa porukassa saattaa niin sanotusti tyhmyys tiivistyä, että keksitäänkin jotain, että eihän me pirulauta tällaista tarvitakaan, niin muutkin on sitä mieltä, että ei me tarvitakaan tämmöistä, tää on jotain ihan humpuukkia. (työnantaja)

Koulutusinnovaatioiden omaksuminen ja leviäminen organisaatiossa on sidoksissa johtamiseen ja organisaation sosiaaliseen ilmapiiriin (ks. Damanpour 1991; myös Kock, Gill \& Ellström 2008).

\section{Sosiaalinen tunnustus ja imago}

Vähän koulutettujen aikuisten integroiminen mukaan koulutukseen edellyttää Huttusen (2007, Honneth \& Fraser 2004) mukaan sosiaalista tunnustamista mikrotasolla. Koulutukseen epäilevästi suhtautuva henkilö haluaa ennen osallistumispäätöksen tekoa varmistua siitä, minkälainen sosiaalinen imago tutkinnolla on, ja minkälainen tutkinnon havaittavuus on työpaikalla (Deffuant ym.
2005; Nelson ym. 2004). Havaittavuus liittyy esimerkiksi siihen, millä tavoin työtehtävät tai henkilön sosiaalinen asema muuttuvat tutkinnon suorittamisen jälkeen.

Julkinen tiedottaminen ja arvon anto suoritetuista opinnoista voi toimia koulutusinnovaation leviämistä ja sosiaalista havaittavuutta edistävänä motivointikeinona (Nelson ym. 2004). Varsinkin niillä toimialoilla, joiden arvostus on matala, julkisen tiedottamisen avulla haluttiin nostaa alan ja tutkintojen arvostusta.

Ja nimenomaan tässä vaiheessa kun työntekijät suoritti tutkintoja myös paikallislehti pyydettiin mukaan ja tuli niin kuin sellaista, haluttiin saada vähän julkisuutta tälle toiminnalle, kun kuitenkin pienestä paikkakunnasta on kysymys ja tämmöisestä alasta, mikä ei yleensä hirveästi ole esillä, että meilläkin kehitetään tätä osaamista. (työnantaja)

Julkisen tiedottamisen avulla korostetaan tutkinnon suorittamisen arvoa ja nostetaan alan arvostusta.

\section{Johtopäätökset}

Vähän koulutettujen aikuisten koulutusinnovaation omaksuminen näyttää pääpiirteissään noudattavan diffuusioteorian periaatteita. Innovaation omaksumista edesauttoivat koulutuksesta saatavien hyötyjen tiedostaminen, aikaisempien osallistujien jakamat myönteiset kokemukset koulutuksesta sekä mahdollisuus osatutkintojen suorittamiseen. Innovaation diffuusioon vaikuttivat aineistomme perusteella muutosagenttien ja mielipidejohtajien toiminta. Mielipidejohtajuus on organisaation sosiaalisessa järjestelmässä ansaittu ominaisuus, joka on yhteydessä henkilön pätevyyteen, sosiaaliseen lähestyttävyyteen sekä yhdenmukaisuuteen järjestelmän normien kanssa (Rogers 2003). Tämä aineisto korosti mielipidejohtajien merkitystä vähän koulutettujen aikuisten koulutuspäätöksen tekemisessä. Viralliselta taholta tulevan koulutusinformaation sijasta vähän koulutetut aikuiset luottavat vertaisryhmältä saatuihin koulutuskokemuksiin. Myönteiset viestit edistivät koulutusinnovaation omaksumista, kun taas tyytymättömyys ja ristiriitaiset viestit estivät ja hidastivat sitä.

Päätöksenteon kannalta merkityksellistä oli työnantajalta saatu tuki ja kannustus koulutukseen osallistumiselle. Koulutuksen sosiaalinen arvostus edisti koulutusinnovaation leviämistä. 
Sosiaalinen tunnustus erityisesti mikrotasolla oli työnantajien mukaan Nosteen kohderyhmälle tärkeää (Huttunen 2007; Honneth \& Fraser 2004; Hulkari 2008). Aineiston perusteella koulutusinnovaation omaksumista edistivät toimintaympäristöstä nousevat henkilöstön kehittymistavoitteet ja työyhteisön paine. Vähän koulutettuja aikuisia motivoi osallistumaan työelämälähtöisesti järjestetty koulutus, joka oli yhteydessä konkreettisiin työtehtäviin. Koulutukseen osallistumista rajoittavat usein sosioekonomiset esteet sekä negatiiviset mielikuvat koulutuksesta (Jensen 1999; Manninen 2004). Tutkinnon suorittamiseen motivoi henkilökohtaisia oppimistavoitteita enemmän työmarkkina-aseman parantaminen.

Rogersin (1995; myös Nelson ym. 2004) teoriassa monimutkaisuus on yksi innovaation omaksumista estävä tekijä. Vähän koulutettujen aikuisten ryhmässä monimutkaisuus oli yhteydessä koulutuspalvelujen saatavuuteen. Varsinkin matalapalkkaisille ja kolmivuorotyötä tekeville henkilöille työpaikalla tai lähellä asuinpaikkaa järjestettävä koulutus oli edellytyksenä koulutukseen osallistumiselle. Matalapalkkaisille henkilöille koulutukseen osallistuminen on ennen kaikkea taloudellinen kysymys. Koulutuksesta saatavien hyötyjen tulisi olla koulutuksesta aiheutuvia kustannuksia suuremmat.

Matalasti koulutettujen henkilöiden mielikuvat koulutuksesta ovat usein korkeammin koulutettuja negatiivisemmat (esim. Manninen 2004). Nosteohjelmassa negatiivisia mielikuvia on pyritty muokkaamaan positiivisemmiksi helpottamalla koulutuksen saatavuutta ja lisäämällä koulutusjärjestelyjen joustavuutta ja aikuiskoulutuksen kiinnostavuutta. Monille matalasti koulutetuille aikuisille Noste-ohjelma on avannut uusia työuria, raivannut osallistumisen esteitä sekä auttanut opiskelijaa huomaamaan omat mahdollisuutensa ja voimavaransa. Yksilön aktiivinen rooli osaamisen kehittämisessä korostuu entisestään, kun pysyvät työroolit ja työelämän rakenteet hajoavat (myös Eteläpelto 2007; Järvensivu 2006).

Koska osa kohderyhmästä on kuulunut niin sanottuihin myöhäisiin omaksujiin, on Nosteessa pitänyt käyttää perinteisestä koulutusmarkkinoinnista eroavia keinoja kohderyhmän saavuttamiseksi. Paras tapa koulutustiedon levittämisessä on ollut henkilökohtaiset kontaktit kohderyhmän kanssa (Kosonen 2008; Kankaanrinta 2009). Matalasti koulutetuille aikuisille on tärkeää tieto siitä, että opinnot keskittyvät olennaisiin, työn tekemistä helpottaviin opintoihin.

Koulutuksen järjestäjiä tulisi jatkossakin ohjata aikuiskoulutuksessa sellaisiin toimintamalleihin, jotka edistäisivät vähiten koulutusta saaneen ryhmän osallistumista koulutukseen ja myönteisten koulutuskokemusten saamista. Tietoa vähän koulutettujen aikuisten koulutusinnovaation omaksumisesta ja levittämisestä tulisi levittää koulutustoimijoiden käyttöön.

\section{Lähteet}

Abrahamson, E. \& Rosenkopf, L. (1997). Social Network Effects on the Extent of Innovation Diffusion: A Computer Simulation. Organization Science 8 (3), 289-309. Myös http:// www-management.wharton.upenn.edu/rosenkopf/documents/2006/ social_network_effects1.pdf

Ahire, S. L. \& Ravichandran, T. (2001). An innovation diffusion model of TQM implementation. IEEE Transactions on Engineering Management 48 (4), 445-464.

Antikainen, A. (2005). Aikuiskoulutukseen osallistumisen erojen syyt. Julkaisussa U. Rönnberg (toim.) Aikuiskoulutuksen vuosikirja. Opetusministeriön julkaisuja 20. Helsinki, 2332.

Antikainen, A. (2007). Aikuiskoulutus ja yhteiskunnan arvot - Miten vastata kilpailuyhteiskunnan haasteisiin? Koulutuksen yhteiskunnallis-kulttuurisen tutkimuksen yksikkö. Joensuun yliopisto, www-osoitteessa: http://cc.joensuu.fi/anti/publ/uudet/ aikuiskoulutus_ja_arvot.pdf

Antikainen, A. (2009). Aikuiskoulutukseen osallistuminen ja Noste. Teoksessa Noste-ohjelma - aikuiskoulutuksen harppaus. Opetusministeriön julkaisuja 2009:35, 14-18. Saatavissa http://noste-ohjelma.fi.

Berranger, P., Tucker, D. \& Jones, L. (2001). Internet diffusion in creative micro-businesses: identifying change agent characteristics as critical success factors. Journal of Organizational Computing and Electronic Commerce 11 (3), 197-214.

Blomqvist, I., Ruuskanen, T, Niemi, H. \& Nyyssönen, E. (2002). Osallistuminen aikuiskoulutukseen. Aikuiskoulutustutkimus 2000. Koulutus 2002:5. Helsinki: Tilastokeskus. 
Caldwell, R. (2003). Models of change agency: a fourfold classification. British Journal of Management 14, 131-142.

Damanpour, F. (1991). Organizational innovation: a meta-analysis of effects of determinants and moderators. Academy of Management Journal 34 (3), 555-590.

Deffuant, G., Huet, S. \& Amblard, F. (2005). An individual-based model of innovation diffusion mixing social value and individual benefit. American Journal of Sociology 110 (4), 1041-1069.

Eteläpelto, A. 2007. Työidentiteetti ja subjektius rakenteiden ja toimijuuden ristiaallokossa. Teoksessa A. Eteläpelto, K.Collin, J. Saarinen (toim.) Työ, identiteetti ja oppiminen. Helsinki: WSOY Oppimateriaalit Oy.

Fullan, M. (2007). The New Meaning of Educational Change. Fourth edition. New York, London: Teachers College Press, Columbia Univercity.

Fraser, N. \& Honneth, A. (2004). Introduction: Redistribution or Recognition? Teoksessa Redistribution or Recognition? New York: Verso.

Hulkari, K. (2008). Kannattava investointi vai riskibisnestä? Työnantajien käsityksiä aikuiskoulutuksen vaikuttavuudesta ja verkostoyhteistyöstä Noste-ohjelman aikana. Ammattikasvatuksen tutkimus- ja koulutuskeskus. Tampereen yliopisto. Saatavissa http://noste-ohjelma.fi.

Huusko, A. \& Luukkainen, A. (2007). Vaikuttava hakeva toiminta Noste-hankkeissa. Joensuun yliopisto. Koulutuksen yhteiskunnalliskulttuurisen tutkimuksen yksikkö. Saatavissa http://noste-ohjelma.fi.

Huttunen, R. (2007). Critical Adult Education and the Politicalphilosophical Debate Between Nancy Fraser and Axel Honneth. Educational Theory 57(4), 423-433.

Illeris, K. (2004). Adult Education and Adult Learning. Malabar: Krieger.

Illeris, K. (2006). Elinikäinen oppiminen ja matalasti koulutetut. Aikuiskasvatus 26 (1), 4-13. Helsinki: Kansanvalistusseura Aikuiskasvatuksen tutkimusseura.

Jensen, R. (1999). The Dream Society: How the Coming Shift from Information to Imagina- tion Will Transform Your Business. New York: McGraw-Hill.

Järvensivu, A. (2006). Oppiminen työnä ja työpaikkapelinä. Tampereen yliopisto Kasvatustieteiden tiedekunta. Aikuiskasvatuksen väitöskirja. Tampere: University Press.

Kaivola, T. (2000). GLOBE-ohjelma ympäristökasvatuksen innovaationa Suomessa. Helsinki: Helsingin yliopisto, opettajankoulutuslaitos. Tutkimuksia 218.

Kankaanrinta, I-K. (2009). Virtuaalimaailmoja valtaamassa - verkko-opetusinnovaation leviäminen koulun maantieteeseen vuosituhannen vaihteessa. Käyttäytymistieteen väitöskirja. Helsinki: Helsingin yliopisto. Tutkimuksia 296.

Kokkila, H. (2006). Ammattitutkinto aikuisiällä. Noste-koulutukseen hakeutuminen osana aikuisten elämänkulkua. Joensuun yliopisto. Koulutuksen yhteiskunnallis-kulttuurisen tutkimuksen yksikkö. Saatavissa http://noste-ohjelma.fi.

Kolehmainen, S. (1997). Innovaatioiden diffuusio ammattikorkeakoulureformissa. Tampereen yliopisto. Acta Universitatis Tamperensis 543 .

Kosonen, T. (2008). Nosteen hakeva toiminta vuodesta 2003 vuoteen 2007 ja eteenpäin. Joensuun yliopisto. Koulutuksen yhteiskunnallis-kulttuurisen tutkimuksen yksikkö. Saatavissa http://noste-ohjelma.fi.

Kuncaits, R. (2005). Participation in Adult Education: Lithuanian case. Paper presented in The 5th ERDI Expert Seminar, 21.-23.1.2005. Bonn

Laukkanen, H. (2006). Ammattitutkinto aikuisiällä - Noste-koulutukseen hakeutuminen osana aikuisten elämänkulkua. Joensuun yliopisto. Koulutuksen yhteiskunnallis-kulttuurisen tutkimuksen yksikkö. Saatavissa http://noste-ohjelma.fi.

Laukkanen, H. (2008). Vertaistuki ja verkostot vahvuutena. SAK:n pätevyysluotsien ja Nostehankkeiden hyviä yhteistyökäytäntöjä. Käsikirjoitus.

Manninen, J. (2004). Mielikuvat ohjaavat aikuisten osallistumista koulutukseen. Aikuiskasvatus 24 (3), 196-205.

Manninen, J., Mannisenmäki, E., Luukannel, S. \& Riihilä, S. (2003). Elinikäisen oppimisen 
tuska ja kurjuus? Aikuisten koulutusta ja oppimista koskevat mielikuvat. Raportteja ja selvityksiä 42. Helsinki: Palmenia-kustannus.

Nelson, R. R., Peterhansl, A. \& Sampat, B. (2004). Why and how innovations get adopted: a tale of four models. Industrial and Corporate Change 13 (5), 679-699.

Plouffe, C.R., Vandenbosch M. \& Hulland J. (2001). Intermediating technologies and multi-group adoption: A Comparison of consumer and merchant adoption intentions toward a new electronic payment system. The Journal of Product Innovation Management, 18, 65-81.

Pohjanpää, K., Niemi, H. \& Ruuskanen, T. (2008). Osallistuminen aikuiskoulutukseen. Aikuiskoulutustutkimus 2006. Koulutus 2008. Helsinki: Tilastokeskus.

Rogers, E. M. (1995). Diffusion of Innovations. Fourth edition. New York: The Free Press.

Rogers, E. M. (2003). Diffusion of Innovations. Fifth edition. New York: The Free Press.

Ruohotie, P. (2000). Oppiminen ja ammatillinen kasvu. Helsinki: WSOY.

Seels,, B. (1997). Taxonomic Issues and the Development of Theory in Instructional Technology. Educational Technology 37 (1), 12-21.

Sevcik, P. (2004). Innovation diffusion. Business Communications Review, September, 8-11
Tikkanen, T. \& Nyhan, B. (2008). Introduction: innovative learning measures for older workers. Teoksessa Innovative learning measures for older workers. Luxembourg: Cedefop Panorama Series 159.

Tossavainen, J. (2008a). Matalasti koulutetut aikuiset Hakevan toiminnan tutkimuksen ja Aikuiskoulutustutkimuksen näkökulmasta. Joensuun yliopisto. Koulutuksen yhteiskunnallis-kulttuurisen tutkimuksen yksikkö. Saatavissa http://noste-ohjelma.fi.

Tossavainen, J. (2008b). Työnantajakatsaus syksy 2008. Työnantajien näkökulmia Nosteen kohderyhmään, hakevaan toimintaan ja toimijoiden koulutusmotiiveihin. Joensuun yliopisto. Koulutuksen yhteiskunnallis-kulttuurisen tutkimuksen yksikkö. Saatavissa http:// noste-ohjelma.fi.

Tuomi, J. \& Sarajärvi, A. (2006). Laadullinen tutkimus ja sisällönanalyysi. Helsinki: Tammi.

Waarts, E. \& Everdingen, Y. \& Hillegersberg, J. 2002. The dynamics of factors affecting the adoption of innovations. Journal of Product Innovation Management 19(6), 412 - 423.

Weiman,G. (1994). The influentials: People who influence people. New York : State University of New York Press.

Artikkeli saapui toimitukseen 8.1.2009. Se hyväksyttiin julkaistavaksi toimituskunnan kokouksessa 30.11.2009. 